\title{
Immune status of the neonate maintained on total parenteral nutrition
}

\author{
P PURI, D J REEN, ORLA BROWNE, AND E J GUINEY \\ Children's Research Centre, Our Lady's Hospital for Sick Children, and Department of Pathology, \\ Royal College of Surgeons in Ireland, Dublin
}

\begin{abstract}
SUMMARY Immunological studies were carried out on 7 neonates maintained on total parenteral nutrition for periods ranging from 14 to 31 days after surgery for correction of gastrointestinal anomalies. IgM and IgA levels were high in all patients but IgG levels were low, compared with normal values. Total leucocyte counts, absolute lymphocyte counts, and T- and B-lymphocytes in all patients were similar to those of healthy controls. Neonates maintained on adequate total parenteral nutrition showed no evidence of impairment of immune function.
\end{abstract}

In early postnatal life calorie restriction impedes cell division, organ growth, and differentiation, and may result in permanent stunting and retardation of brain growth. Later in life, undernutrition affects cell size and composition, but this may be reversible after nutritional recovery. ${ }^{1}$

The most prominent association of nutritional deficiency is with infection. ${ }^{2}$ It is known that undernutrition in late fetal and early postnatal life impairs the ability of the infant to respond to infections. Several aspects of immunocompetencesuch as T-cell number, cell-mediated immunity, polymorphonuclear cell function, antibody responses, and complement components-are diminished in human undernutrition. ${ }^{3-5}$ Similar defects are seen in infants of low birthweights who also have intrauterine malnutrition. ${ }^{6}$

Malnutrition readily develops if there is failure of gastrointestinal function after surgical correction of severe gastrointestinal malformations, after prolonged gastroenteritis, and in very low birthweight preterm infants. The neonate with its relatively high metabolic rate, its requirements for growth, and its limited calorie stores is particularly susceptible to the effects of starvation. ${ }^{7}$ With the advent of parenteral nutrition it has become possible to provide metabolic support to those infants who would otherwise have suffered from prolonged periods of malnutrition because of temporary, but total, gastrointestinal malfunction.

Although the technical and metabolic aspects of total parenteral nutrition (TPN) and its complications have been studied, the immune status of the neonate maintained on TPN has not. The purpose of this study was to assess immune function in neonates maintained on long-term parenteral nutrition and to compare this with the immune status of healthy neonates.

\section{Material and methods}

Patients. Seven neonates ( 4 boys and 3 girls) receiving total parenteral nutrition for periods ranging from 14 to 31 days were evaluated for immunoglobulins and complement levels, total leucocyte and absolute lymphocyte counts, and Tand B-lymphocyte subpopulations. Their mean gestational age was $39 \cdot 5$ (range 38-41) weeks and their mean birthweight 2.9 (range 2.1 to 3.9 ) $\mathrm{kg}$. The indications for TPN were gastroschisis (2), massive small-bowel resection (2), anastomotic leak after repair of tracheo-oesophageal fistula (2), and reoperation for anastomotic leak in jejunal atresia (1). The age at which TPN was begun ranged from 1 to 6 (with a mean of 3) days.

The regimen used for TPN was similar to that reported previously. ${ }^{8}$ The infusate consisted of four basic solutions: (1) Vamin, composed of amino-acids, glucose, and electrolytes, (2) $20 \%$ Intralipid, containing the fat emulsion, (3) $10 \%$ glucose, and (4) $4.3 \%$ glucose in $0.18 \%$ saline. This regimen provided a daily calorie intake of between 100 and 120 calories $/ \mathrm{kg}$ and a daily water intake of $150 \mathrm{ml} / \mathrm{kg}$. Daily requirements of vitamins and minerals were added to $10 \%$ glucose. Plasma was given once a week to provide trace elements.

Controls. Thirty term neonates were evaluated for total leucocytes and absolute lymphocyte counts, 
and T- and B-lymphocyte subpopulations. After determining the parent's willingness to participate in the study, samples of venous blood were obtained from the neonate on day 1 , day 5 , and day 20 after birth. The cumulative mean values obtained on the 3 separate days of testing are described as the normal neonatal control values. Cord blood samples from 25 healthy term neonates were estimated for IgG, IgA, IgM, and $\mathrm{C} 3$ and $\mathrm{C} 4$ levels.

\section{Immunological studies.}

\section{Immunoglobulins and complement components}

IgG, IgA, IgM, and $C 3\left(\beta_{1} C / \beta_{1} A\right)$, and $C 4\left(\beta_{1} E\right)$ levels were determined quantitatively by the automated immunoprecipitation technique from Technicon Corp. Tarrytown, NY, using PEG 6000 diluent for maximum sensitivity. ${ }^{9}$

\section{Total leucocyte and absolute lymphocyte counts}

Leucocyte counts were made on an electronic cell counter (Coulter Counter Model ZF) and the differential cell counts were made on blood smears using Giemsa stain.

$T$ - and B-lymphocytes

Spontaneous erythrocyte rosette-forming lympho- cytes (T-cells) were estimated after they had been incubated first at $37^{\circ} \mathrm{C}$ for 10 minutes and then at $4^{\circ} \mathrm{C}$ for 18 hours. SmIg-positive lymphocytes (Bcells) were evaluated using fluorescein-conjugated antiserum to whole immunoglobulin as described previously. ${ }^{10}$

Statistical method. Significance of difference between mean patient and control values for immunoglobulin levels based on log-transformed data was calculated using Student's $t$ test for two independent observations. ${ }^{11}$

\section{Results}

All 7 infants survived the period of parenteral nutrition. There was no septicaemia nor was there any other major infection during the period of observation. All infants showed a satisfactory weight gain while on TPN.

Immunoglobulins. The levels of $\operatorname{IgA}$ and $\operatorname{IgM}$ were significantly $(P<0.001)$ raised throughout the period of TPN compared with normal neonatal values (Table 1). However, the mean IgG levels were

Table $1 \operatorname{Ig} G, \operatorname{Ig} A$, and IgM in neonates on total parenteral nutrition

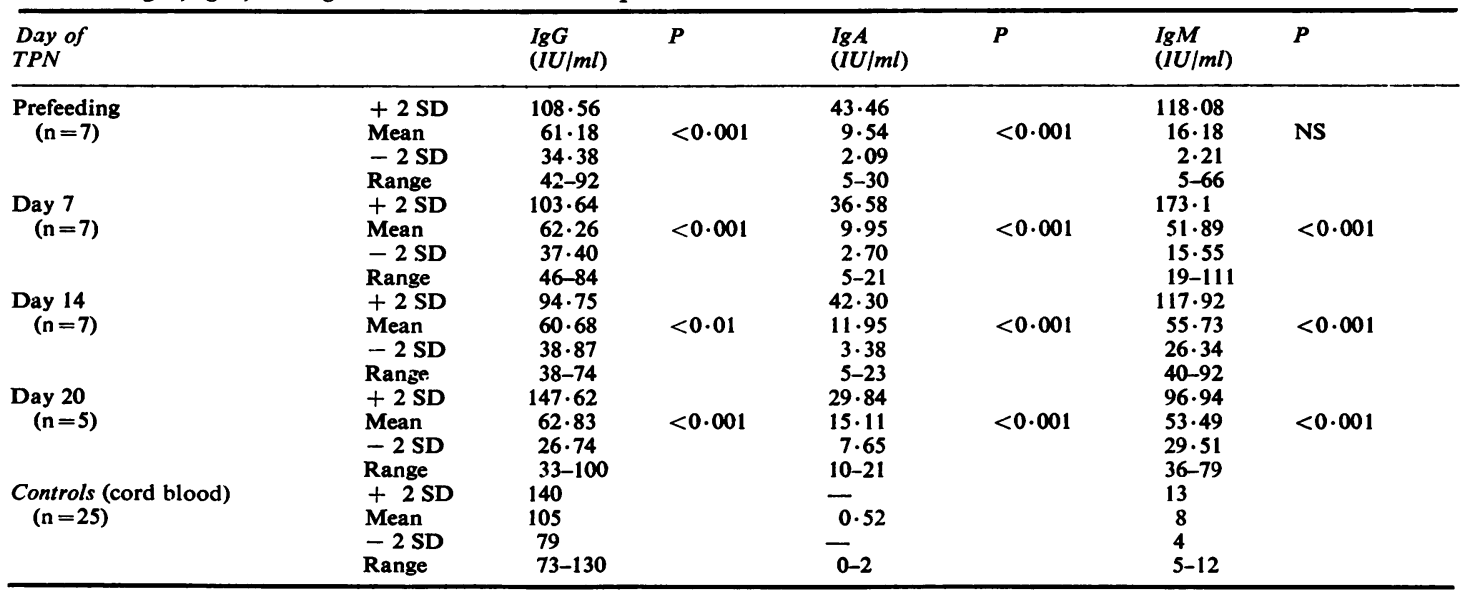

NS = not significant $(P>0.01)$.

Table 2 C3 and C4 levels in neonates on total parenteral nutrition

\begin{tabular}{|c|c|c|c|c|c|c|}
\hline \multirow[t]{2}{*}{ Day of TPN } & \multicolumn{3}{|l|}{$C 3(g / l)$} & \multicolumn{3}{|l|}{$C 4(\mathrm{~g} / \mathrm{l})$} \\
\hline & Range & Mean $\pm 1 S D$ & $\boldsymbol{P}$ & Range & Mean $\pm I S D$ & $\boldsymbol{P}$ \\
\hline $\begin{array}{l}\text { Prefecding }(n=7) \\
\text { Day } 7(n=7) \\
\text { Day } 14(n=7) \\
\text { Day } 20(n=5) \\
\text { Controls (cord blood) }(n=25)\end{array}$ & $\begin{array}{l}0 \cdot 52-1 \cdot 55 \\
0 \cdot 73-1 \cdot 33 \\
0 \cdot 67-1 \cdot 90 \\
0 \cdot 86-1 \cdot 50 \\
0 \cdot 55-1 \cdot 36\end{array}$ & $\begin{array}{l}1 \cdot 01 \pm 0 \cdot 13 \\
1 \cdot 06 \pm 0.08 \\
1 \cdot 33 \pm 0 \cdot 16 \\
1 \cdot 09 \pm 0 \cdot 11 \\
0.93 \pm 0.22\end{array}$ & $\begin{array}{l}\text { NS } \\
\text { NS } \\
\text { NS } \\
\text { NS }\end{array}$ & $\begin{array}{l}0.11-0.28 \\
0 \cdot 10-0.33 \\
0.09-0.34 \\
0.14-0.26 \\
0.05-0.13\end{array}$ & $\begin{array}{l}0 \cdot 16 \pm 0.02 \\
0 \cdot 14 \pm 0.03 \\
0 \cdot 19 \pm 0.03 \\
0 \cdot 16 \pm 0.02 \\
0 \cdot 10 \pm 0.04\end{array}$ & $\begin{array}{l}\text { NS } \\
\text { NS } \\
\text { NS } \\
\text { NS }\end{array}$ \\
\hline
\end{tabular}

NS = not significant $(P>0.01)$. 
Table 3 Total leucocyte and absolute lymphocyte counts in neonates maintained on total parenteral nutrition

\begin{tabular}{|c|c|c|c|c|c|}
\hline \multirow[t]{2}{*}{ Cases } & \multirow{2}{*}{$\begin{array}{l}\text { Duration } \\
\text { of TPN } \\
\text { (days) }\end{array}$} & \multicolumn{2}{|c|}{ Total leucocyte count $\left(\times 10^{9} / \mathrm{l}\right)$} & \multicolumn{2}{|c|}{ Absolute lymphocyte count $\left(\times 10^{9} / l\right)$} \\
\hline & & Range & $M e a n \pm 1 S D$ & Range & $M e a n \pm 1 S D$ \\
\hline $\begin{array}{l}1 \\
2 \\
3 \\
4 \\
5 \\
6\end{array}$ & $\begin{array}{l}27 \\
21 \\
31 \\
26 \\
17 \\
14\end{array}$ & $\begin{array}{r}4 \cdot 5-24 \cdot 6 \\
7 \cdot 9-16 \cdot 6 \\
10 \cdot 2-32 \cdot 8 \\
13 \cdot 0-25 \cdot 9 \\
9 \cdot 6-12 \cdot 2 \\
14 \cdot 9-21 \cdot 8\end{array}$ & $\begin{array}{l}14 \cdot 0 \pm 4 \cdot 3 \\
12 \cdot 0 \pm 1 \cdot 6 \\
19 \cdot 0 \pm 4 \cdot 6 \\
16 \cdot 7 \pm 2 \cdot 3 \\
12 \cdot 0 \pm 1 \cdot 0 \\
17 \cdot 9 \pm 2 \cdot 0\end{array}$ & $\begin{array}{l}3 \cdot 4-8 \cdot 1 \\
3 \cdot 0-5 \cdot 8 \\
2 \cdot 2-5 \cdot 9 \\
3 \cdot 8-10 \cdot 9 \\
4 \cdot 0-8 \cdot 4 \\
4 \cdot 1-7 \cdot 4\end{array}$ & $\begin{array}{l}5 \cdot 3 \pm 1 \cdot 0 \\
4 \cdot 3 \pm 0 \cdot 5 \\
4 \cdot 1 \pm 0 \cdot 7 \\
5 \cdot 3 \pm 1 \cdot 4 \\
5 \cdot 3 \pm 0 \cdot 8 \\
5 \cdot 7 \pm 1 \cdot 0\end{array}$ \\
\hline Controls (neonates) & & $8 \cdot 1-47 \cdot 0$ & $19 \cdot 4 \pm 5 \cdot 0$ & $2 \cdot 4-15 \cdot 0$ & $6 \cdot 8 \pm 0 \cdot 3$ \\
\hline
\end{tabular}

Table 4 Absolute numbers of E-binding lymphocytes (T-cells) and SmIg-positive lymphocytes (B-cells) in neonates on total parenteral nutrition

\begin{tabular}{|c|c|c|c|c|c|}
\hline \multirow[t]{2}{*}{ Cases } & \multirow{2}{*}{$\begin{array}{l}\text { Duration } \\
\text { of TPN } \\
\text { (days) }\end{array}$} & \multicolumn{2}{|c|}{$T$-cells $\left(\times 10^{9} / l\right)$} & \multicolumn{2}{|c|}{ B-cells $\left(\times 10^{9} / l\right)$} \\
\hline & & Range & $M e a n \pm 1 S D$ & Range & $M e a n \pm 1 S D$ \\
\hline $\begin{array}{l}1 \\
2 \\
3 \\
4 \\
5 \\
6\end{array}$ & $\begin{array}{l}27 \\
21 \\
31 \\
26 \\
17 \\
14\end{array}$ & $\begin{array}{l}2 \cdot 3-5 \cdot 4 \\
2 \cdot 0-4 \cdot 1 \\
1 \cdot 1-3 \cdot 2 \\
1 \cdot 0-9 \cdot 3 \\
1 \cdot 8-5 \cdot 3 \\
3 \cdot 1-5 \cdot 6\end{array}$ & $\begin{array}{l}3 \cdot 7 \pm 0 \cdot 6 \\
2 \cdot 7 \pm 0 \cdot 4 \\
2 \cdot 2 \pm 0 \cdot 3 \\
3 \cdot 8 \pm 1 \cdot 1 \\
2 \cdot 8 \pm 0 \cdot 7 \\
4 \cdot 1 \pm 0 \cdot 7\end{array}$ & $\begin{array}{l}0.57-0.77 \\
0.39-0.83 \\
0.54-1.30 \\
0.54-2 \cdot 17 \\
0.91-1.67 \\
0.21-1.00\end{array}$ & $\begin{array}{l}0.70 \pm 0.06 \\
0.64 \pm 0.1 \\
0.89 \pm 0.19 \\
1.05 \pm 0.28 \\
1 \cdot 16 \pm 0 \cdot 13 \\
0.73 \pm 0.26\end{array}$ \\
\hline Controls (neonates) & & $0.9-8.7$ & $4 \cdot 0 \pm 0 \cdot 2$ & $0.49-3.59$ & $1.49 \pm 0.18$ \\
\hline
\end{tabular}

persistently low $(P<0.001)$ in all 7 infants during the period of study.

Complement. The mean levels of complement $\mathrm{C} 3$ and C4 components were not significantly different from normal mean neonatal values $(P>0 \cdot 01)$ (Table 2$)$.

Total leucocyte and absolute lymphocyte counts. The mean total leucocyte count showed a wide variation in number both in infants on TPN (range 12.0 \pm 1.0 to $\left.19.0 \pm 4.6 \times 10^{9} / 1\right)$ and in normal healthy neonates $\left(19.4 \pm 5.0 \times 10^{9} / 1\right)$ (Table 3). The mean absolute lymphocyte count in neonates on TPN (range $4.1 \pm 0.7$ to $5.7 \pm 1.0 \times 10^{9} / 1$ ) was lower, but not significantly so, than the normal neonatal values $\left(6 \cdot 8 \pm 0 \cdot 3 \times 10^{9} / 1\right)$.

T- and B-lymphocytes. The Figure shows the percentage of T- and B-lymphocytes in infants on TPN. The percentage of T- and B-cells remained within or slightly above the determined range (mean \pm 1 SD) for healthy normal neonates. The lower levels for percentage of T-cells observed in the controls during the early neonatal period were also seen in infants on TPN during the early neonatal period. The absolute numbers of E-rosettes (T-cells) in all the infants were similar to the normal neonatal values while the numbers of B-cells were slightly diminished (Table 4).

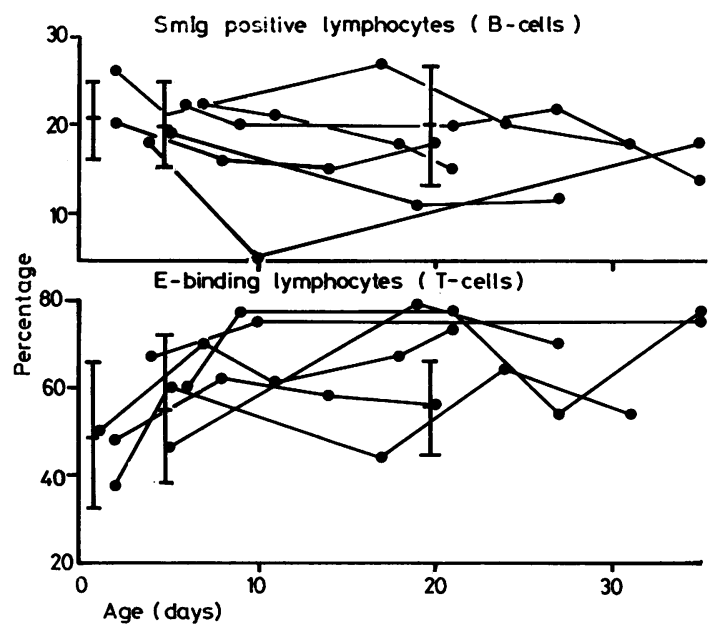

Figure Percentage of $T$-cells and B-cells in neonates during maintenance on total parenteral nutrition.

Vertical lines represent normal neonatal values $\pm 1 S D$ on day 1, day 5, and day 20.

\section{Discussion}

Neonates, particularly after surgery, have an increased susceptibility to overwhelming infection from opportunistic organisms. Moreover, several 
studies have confirmed the long-held clinical impression that infectious diseases adversely affect nutritional status, ${ }^{412}$ and infection per se can impair immune function. ${ }^{5}$ Therefore the relationship between nutrition, immunity, and infection-particularly in infants-is important since the neonate is unique in its vulnerability to nutrient insufficiency during illness.

Current regimens for TPN in the neonate are based on maintaining satisfactory weight gain and normal biochemical values, and on providing sufficient calories to meet the daily requirements of the developing infant. All infants in our study showed adequate weight gain, normal growth and development, as well as normal wound healing.

Our results suggest that infants adequately maintained on TPN are capable of antibody synthesis in response to antigenic stimulus as evident from increased IgM and $\operatorname{IgA}$ levels. The raised IgM levels suggest an active subclinical infective process, since IgM is the initial antibody produced in the circulation in response to a primary infection. This was especially so in this group of infants who all underwent surgery for correction of congenital abnormalities. The raised IgA levels are probably related to the gastrointestinal origin of the primary anomalies in the neonates. The fall in IgG values which in the neonate are largely maternally derived may further reflect ongoing subclinical infection since such passively-acquired maternal IgG used during infective processes is not immediately replenished in the developing neonate.

Further evidence of a functional and active immune system in neonates maintained on TPN is seen in the results of lymphocyte subpopulation studies. The proportions of both T- lymphocyte and B-lymphocyte levels reflect a normal developing lymphocyte mediated immune system. The total leucocyte count and absolute count were also similar to those of normal healthy neonates. However, it is important to note that the neonate is undergoing rapid changes in peripheral blood leucocyte numbers and polymorphonuclear leucocyte-lymphocyte ratio as a consequence of the sudden change of environment after birth, ${ }^{13}$ and this fact must be considered when assessing immune function in the neonate.

While these results do not represent a comprehensive investigation of the complex relationship that exists between nutritional status and the immune capacity of the developing neonate, there was no evidence to suggest impairment of immune function in the neonate adequately maintained on TPN.

\section{References}

1 Winick M. Cellular growth during early malnutrition. Pediatrics 1971; 47: 969-78.

2 Schrimshaw N S, Taylor C E, Gordon T E. Interactions of nutrition and infection. World Health Organisation Monograph Series, No 57. Geneva: WHO, 1968.

3 Antia A U, McFarlane H, Soothill J F. Serum siderophilin in kwashiokor. Arch Dis Child 1968; 43: 459-62.

4 Chandra R K. Immunocompetence in undernutrition. $J$ Pediatr 1972; 81 : 1194-200.

5 Chandra $\mathbf{R}$ K. Interactions of nutrition, infection, and immune response. Acta Paediatr Scand 1979; 68: 137-44.

6 Chandra R K. Rosette-forming T-lymphocytes and cellmediated immunity in malnutrition. $B r$ Med $J$ 1974; iii: 608-9.

7 Heird W C, Driscoll J M, Jr, Schullinger J N, Grebin B, Winters $\mathbf{R}$ W. Intravenous alimentation in pediatric patients. J Pediatr 1972; 80: 351-72.

8 Puri P, Guiney E J, O'Donnell B. Total parenteral feeding in infants using peripheral veins. Arch Dis Child 1975; 50: $133-6$.

9 Killingsworth L M, Buffone G L, Sonewane M B, Lunsford G C. Optimizing nephelometric measurement of specific serum proteins: evaluation of three diluents. Clin Chem 1974; 20: 1548-52.

10 Puri P, Reen D J, Browne O, Blake P, Guiney E J. Lymphocyte response after surgery in the neonate. Arch Dis Child 1979; 54: 599-603.

11 Petrie A. Lecture notes on medical statistics. Oxford: Blackwell, 1978.

12 Ferguson A S, Lawlor G J, Jr, Neumann C G, Oh W, Stiehm E R. Decreased rosette-forming lymphocytes in malnutrition and intrauterine growth retardation. $J$ Pediatr 1974; 85: 717-23.

13 Boxer L A. Immunological function and leucocyte disorders in newborn infants. Clin Haematol 1978; 7: 123-46.

Correspondence to Dr P Puri, Children's Research Centre, Our Lady's Hospital for Sick Children, Crumlin, Dublin 12, Eire.

Received 4 December 1979 